\title{
ANALISIS PENGARUH DYNAMIC SOURCE ROUTING DAN TEMPORALLY ORDERED ROUTING ALGORITHM TERHADAP TABRAKAN DATA PADA VANET
}

\author{
Debby Tri Wulandari $\mathrm{AM}^{1}$, Rendy Munadi $^{2}$, Ratna Mayasari ${ }^{3}$ \\ Jurusan Teknik Telekomunikasi, Universitas Telkom \\ Jl. Telekomunikasi Terusan Buah Batu, Bandung 40257, Indonesia \\ E-mail: ${ }^{1}$ debbytriwulandariam@gmail.com, ${ }^{2}$ rendymunadi@telkomuniversity.ac.id, \\ ${ }^{3}$ ratnamayasari@telkomuniversity.ac.id
}

\begin{abstract}
Abstrak
Perubahan yang sering terjadi dan banyaknya node dapat menyebabkan terjadinya collision atau tabrakan data pada Vehicular Ad-Hoc Network (VANET) yang dapat menyebabkan terjadinya packet loss yang tinggi, sehingga informasi yang dikirim tidak diterima. Oleh karena itu, dibutuhkan sebuah routing yang efisien dalam proses pengiriman data. Dynamic Source Routing (DSR) dan Temporally Ordered Routing Algorithm (TORA) merupakan jenis routing dalam wireless communication. DSR dan TORA termasuk jenis routing berbasis topologi yang bersifat reaktif, dimana jalur untuk menuju node tujuan akan ditentukan ketika paket routing telah sampai dinode tersebut. Hasil simulasi dengan perubahan jumlah node menunjukkan DSR memiliki nilai rata-rata throughput 443,204 kbps, packet delivery ratio $86,25 \%$, packet loss $13,75 \%$, delay $2,78 \mathrm{~ms}$ dan collision rate sebesar 0,12 . Dan untuk TORA memiliki nilai rata-rata throughput $259,04 \mathrm{kbps}$, packet delivery ratio $41,97 \%$, packet loss $57,98 \%$, delay $2,81 \mathrm{~ms}$ dan collision rate sebesar 0,61 .
\end{abstract}

Kata kunci: VANET, Collision, DSR, TORA

\begin{abstract}
Frequent changes and complex nodes may trigger collision on Vehicular Ad-Hoc Network (VANET) and causes packet loss. As a consequence, the information transmitted cannot be received. Therefore, VANET requires an efficient routing to transmit data. Dynamic Source Routing (DSR) and Temporally Ordered Routing Algorithm (TORA) are routing types in wireless communication. DSR and TORA belong to routing type based on topology whose characteristic is reactive. It means the route toward destination node will be determined when the routing packet reach that node. The result of simulation with various number of node shows DSR has an average throughput value of 443,204 kbps, packet delivery ratio $86,25 \%$, packet loss $13,75 \%$, delay $2,78 \mathrm{~ms}$ and collision rate 0,12 . Moreover, result of TORA has an average throughput of $259,04 \mathrm{kbps}$, packet delivery ratio $41,97 \%$, packet loss $57,98 \%$, delay $2,81 \mathrm{~ms}$ and collision rate 0,61 .
\end{abstract}

Keywords: VANET, Collision, DSR, TORA

\section{Pendahuluan}

Jaringan $A d-H o c$ merupakan desentralisasi jaringan wireless dimana jaringan tidak bergantung lagi pada infrastuktur yang ada seperti, router atau access point. Setiap node bertanggungjawab untuk mengirimkan data ke node lain. Node yang bertugas sebagai pengirim data ditentukan berdasarkan konektivitas jaringan itu sendiri.

Vehicular Ad-Hoc Network (VANET) merupakan jaringan $A d-H o c$ yang saat ini sedang dikembangkan untuk mendukung Intelligent Transportation Sytem (ITS) atau sistem transportasi cerdas [1]. Dengan sistem trasportasi cerdas ini, diharapkan mampu membantu pemakai transportasi dalam memperoleh informasi, mempermudah transaksi, mengurangi kemacetan, serta meningkatkan keamanan dan kenyamanan. VANET menggunakan sebuah alat sensor yang disebut On Board Unit (OBU) yang diinstall pada setiap kendaraan dan Road Side Unit (RSU) untuk mengumpulkan data. On Board Unit digunakan untuk melakukan pertukaran informasi dengan kendaraan lain atau access point yang terdapat dijalanan [2].

Tujuan utama VANET adalah memudahkan kendaraan untuk saling berkomunikasi tanpa menggunakan base station atau controller. Arsitektur VANET terbagi dalam tiga jenis yaitu komunikasi antar kendaraan (Inter vehicle 
communication), kendaraan dengan infrastruktur (Vehicle to roadside communication), dan komunikasi antar infrastuktur (Inter roadside communication) [3]. Adapun karakteristik yang dimiliki oleh VANET, yaitu [4] :
a. High mobility of nodes
b. Dynamic topology
c. Frequent Disconnection
d. Limited Bandwith

Mobilitas node yang tinggi dan topologi yang dinamis membuat topologi jaringan pada VANET sering mengalami perubahan [5]. Hal ini dapat memicu terjadinya tabrakan data. Collision merupakan kondisi saat dua atau lebih perangkat mengirim data pada waktu yang bersamaan. Pengiriman paket dari sumber ke tujuan yang dilakukan dengan membagi paket dalam bentuk potongan lebih kecil dapat mengakibatkan terjadinya penumpukan paket dalam satu jaringan. Ketika bandwidth yang digunakan tidak cukup untuk menampung banyak paket yang lewat maka paket-paket tersebut akan rusak diakibatkan collision yang terjadi.

Oleh karena itu, proses routing data pada jaringan VANET menjadi salah satu permasalahan yang perlu diperhatikan karena menjadi permasalahan utama pada VANET [6]. Pada penelitian ini akan dilakukan pengujian Quality of Service (QoS) terhadap dua routing protocol yaitu Dynamic Source Routing (DSR) dan Temporally Ordered Routing Algortihm (TORA) untuk melihat performansi kedua routing tersebut terhadap tabrakan data pada jaringan VANET.

\section{Metode}

\subsection{Routing Protocol}

Routing protocol merupakan suatu metode dalam menemukan rute terbaik dari link yang dilalui antar node sumber ke node tujuan yang berhubungan, dimana pemilihan rute terbaik dilakukan berdasarkan beberapa pertimbangan seperti jarak dan bandwidth link. Secara umum, routing protocol diklasifikasikan ke dalam lima kategori yaitu, Topology based routing protocol, Position based routing protocol, Cluster based routing protocol, Geo cast routing protocol dan Broadcast routing protocol [7].

\subsection{Topology Based Routing}

Routing protocol berbasis topologi menggunakan tabel routing untuk menyimpan informasi link sebagai dasar packet forwarding dari node sumber ke node tujuan. Protokol berbasis topologi terbagi menjadi tiga jenis yaitu proaktif, hybrid, dan reaktif. Pada penelitian ini digunakan protokol routing yang bersifat reaktif. Reaktif routing merupakan routing yang dibangun hanya ketika node sumber membutuhkannya. Saat node sumber membutuhkan routing ke node tujuan, node sumber akan melakukan route discovery dalam jaringan. Proses ini akan selesai jika rute telah ditemukan atau semua permutasi rute telah diperiksa. Setelah rute ditemukan maka akan dilakukan prosedur routing maintenance hingga node sumber tidak menginginkan lagi atau node tujuan tidak bisa diakses lagi. Reaktif routing terbagi menjadi empat yaitu AODV, DSR, AOMDV, dan TORA.

\subsubsection{Dynamic Source Routing}

Pada penelitian ini digunakan routing DSR sebagai metode pengiriman data. DSR membentuk rute sesuai permintaan dan tergantung pada sumber routing daripada tabel routing. DSR merupakan sebuah beacon-less dan tidak menggunakan periodic message sehingga mengurangi bandwith overhead [8]. Routing protocol DSR menerapkan metode flooding dalam mencari rute dan mempunyai fitur source routing dimana node sumber mengetahui rute lengkap menuju node tujuan yang disimpan dalam sebuah memori (cache route) dan diletakkan pada header dalam paket data yang dikirim. Daftar urutan lengkap node memungkinkan paket untuk melakukan pencarian rute dan menghindari kebutuhan pembaharuan pencarian rute dan mengulang informasi secara bebas pada node menengah (intermediate node).

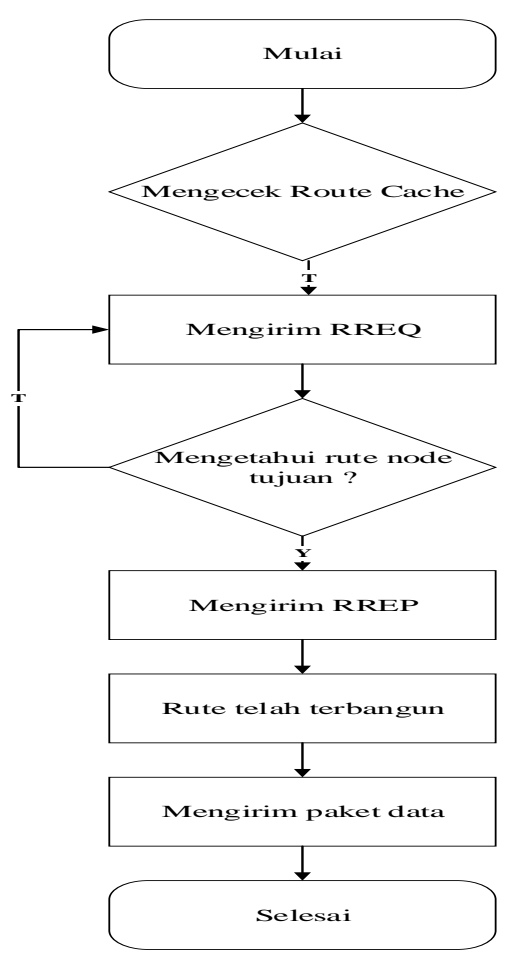

Gambar 1. Diagram Alir Proses Route Discovery DSR

DSR memiliki dua mekanisme kerja yaitu route discovery dan route maintenance. Route discovery terjadi saat sebuah node sumber ingin mengirim paket ke node tujuan, maka node sumber akan melihat route cache miliknya. Jika rute ke tujuan ditemukan maka node akan 
menggunakan informasi yang terdapat di route cache. Jika tidak terdapat informasi apapun mengenai rute tujuan, maka node sumber akan melakukan inisisai protokol pencarian rute. Gambar 1 menunjukkan proses route discovery. Node sumber akan mengirimkan paket Route Request (RREQ) yang berisikan informasi mengenai alamat sumber, tujuan, dan nomor identifikasi yang unik ke semua node tetangga. Setiap intermediate node akan memeriksa apakah dirinya mengetahui rute dari sumber ke node tujuan. Jika node tidak memiliki informasi, maka akan dilakukan penambahan alamat pada catatan paket rute dan meneruskan paket tersebut menuju node tetangga. Setelah penemuan rute telah berhasil, maka node tujuan akan mengirimkan paket Route Replay (RREP) hingga node sumber. Paket RREP berisikan rekapan daftar node yang akan dilewati.

Tahap selanjutnya yaitu proses pemeliharaan rute. Route maintenance terjadi jika terdapat link yang putus dan akan dilakukan update table routing sesuai keinginan node sumber. Node yang terputus akan mengirimkan paket Route Error (RERR) yang berisikan informasi node yang mengalami putus hubungan. Paket RERR akan dikirim ke node sumber, dan node sumber akan menghapus rute tersebut dari route cache dan melakukan pembaharuan table routing [9].

\subsubsection{Temporally Ordered Routing Algortihm}

Pada penelitian ini digunakan routing TORA sebagai metode pembanding. TORA bersifat adaptif dan bebas dari kemungkinan looping dan menggunakan transmisi broadcast untuk melakukan pengiriman data dari node sumber menuju node tujuan sehingga menyediakan beberapa rute untuk sampai ke tujuan. Adapun tipe paket yang digunakan dalam TORA yaitu paket Query (QRY) yang digunakan untuk pembangunan rute, paket Update (UPD) yang digunakan untuk pembangunan dan pemeliharaan rute, dan paket Clear (CLR) yang digunakan untuk penghapusan rute. TORA bekerja berdasarkan height tiap node. Height dari suatu node menentukan path untuk tujuan yang dimaksud. Shoretest path bukan menjadi prioritas pada routing TORA, sehingga penggunaan rute yang panjang masih dipertimbangkan [10].

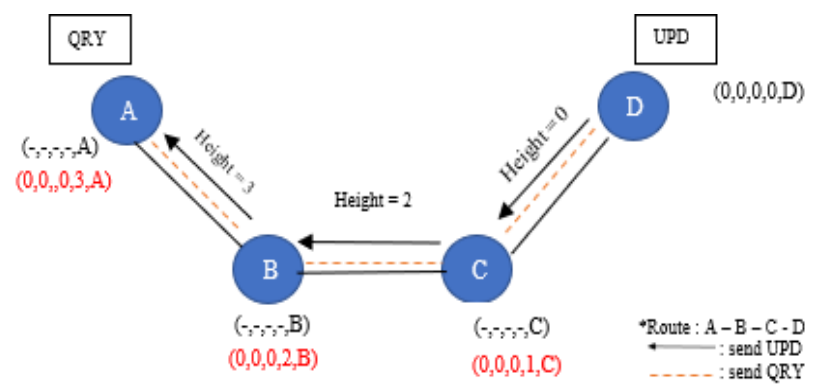

Gambar 2. Proses Route discovery pada TORA
TORA memiliki tiga mekanisme kerja yaitu route discovery, route maintenance dan route erasure [8]. Gambar 2 menunjukkan proses pembuatan routing atau route discovery. Terdapat dua paket yang digunakan pada proses tersebut, yaitu Query dan Update. Query message dikirim dari node sumber ke node tujuan. Saat query message mencapai node tujuan, update message akan digenerate oleh node tujuan. Pesan tersebut akan mulai mengirim height metric secara backwards sehingga node sumber menjadi node terakhir. Height metric berisi semua rute dari tujuan ke sumber. Height metric dengan nilai paling kecil akan dipilih sebagai jalur transmisi data. Pembangunan rute berakhir ketika semua node telah meng-update table routing.

Tahap selanjutnya yaitu proses pemeliharaan rute. Route maintenance dilakukan ketika terjadi perubahan topologi yang dapat disebabkan oleh penambahan jumlah node ataupun pergerakan node. Route maintenance dijalankan hanya untuk node yang memiliki height bukan NULL. Proses pemeliharaan rute menggunakan paket UPD. Ketika terjadi link failure maka sesaat setelah itu node yang mengalami putus hubungan akan memberitahukan kepada node tetangganya melalui link reversal untuk menginformasikan bahwa telah terjadi link failure berupa paket UPD hingga nantinya sampai ke node sumber. Route erase dilakukan dengan mem-broadcast paket clear message jika suatu node mendeteksi adanya bagian yang terpisah dalam suatu jaringan yang disebabkan topologi jaringan yang berubah. Node akan melakukan penghapusan route ketika mendeteksi bahwa bagian tersebut terpisah atau tidak ada jalur menuju tujuan.

\subsection{Perancangan Sistem}

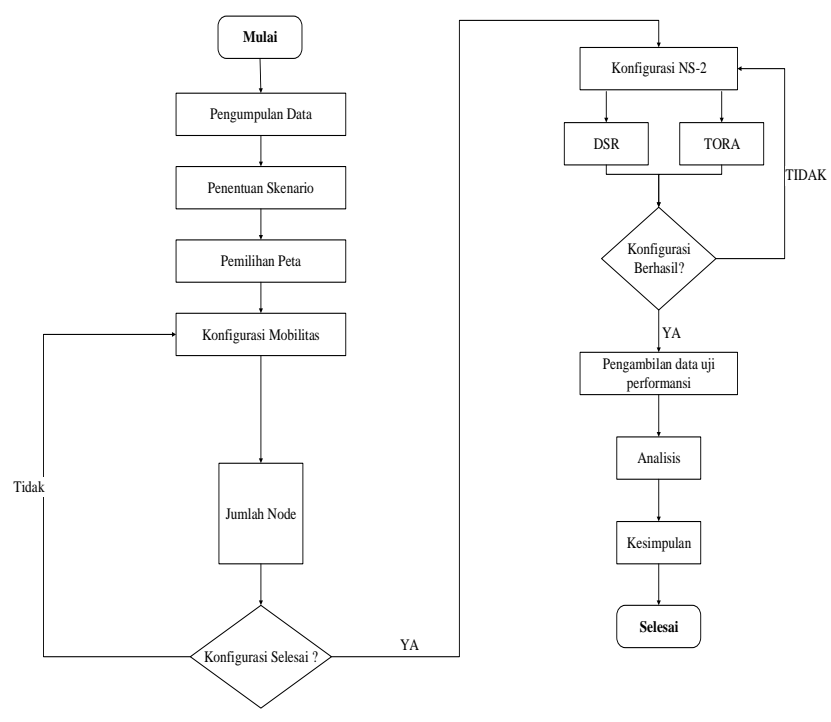

Gambar 3. Perancangan Sistem Penelitian

Pada penelitian ini dilakukan simulasi untuk menganalisis performansi dari protokol routing DSR dan TORA pada jaringan Ad-Hoc VANET dengan menggunakan 
Simulation of Urban Mobility (SUMO) dan Network Simulator. Perancangan sistem penelitian dapat dilihat pada Gambar 3. Simulasi skenario dimulai dengan menentukan peta yang akan digunakan untuk skenario pengujian. Peta diperoleh dari openstreemap.org. Kemudian menentukan parameter kepadatan node untuk memperhatikan pergerakan setiap node menggunakan SUMO. Lalu menentukan data traffic untuk dikirimkan sesuai dengan protokol routing DSR dan TORA yang dilakukan dengan network simulator. Parameter QoS yang diuji adalah throughput, packet delivery ratio, packet loss, delay, dan collision rate terhadap tabrakan data dengan skenario perubahan jumlah node.

\subsubsection{Desain Jaringan}

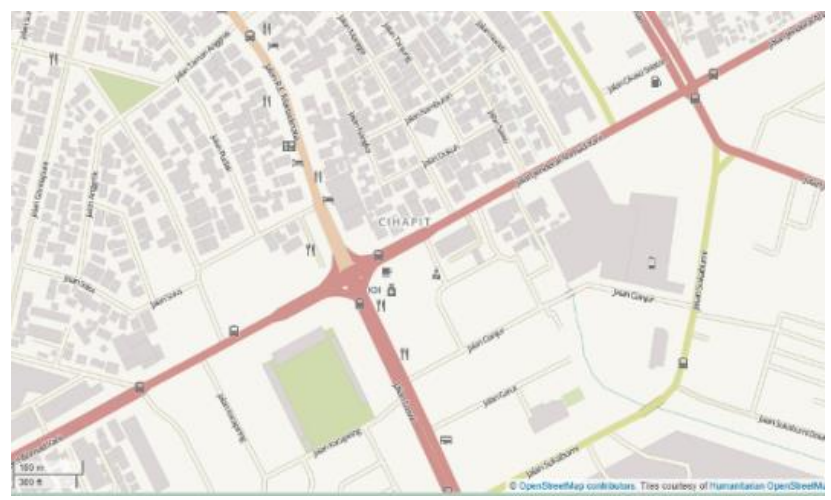

\section{Gambar 4. Peta Skenario}

Desain jaringan pada penelitian ini adalah setiap kendaraan diasumsikan sebagai node, dan antar node akan saling berkomunikasi tanpa adanya Road Site Unit (RSU) atau dikenal dengan istilah Inter Vehicle Communication. Skenario yang digunakan merupakan map based sehingga mendekati kondisi lingkungan yang sebenarnya. Peta yang dipilih sebagai skenario pengujian dapat dilihat pada Gambar 4 yaitu lingkungan perkotaan (urban) di perempatan Stadion Persib (Jalan R.E Martadinata Ahmad Yani) di Kota Bandung.

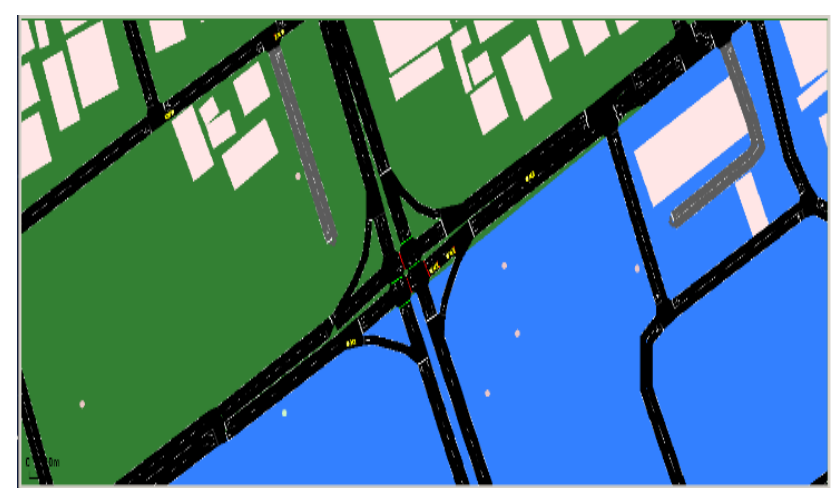

Gambar 5. Tampilan Peta Skenario pada SUMO
Mobilitas jaringan pada penelitian dikonfigurasi menggunakan SUMO versi 0.32.0 yang berfungsi sebagai generator mobility dalam mengatur pergerakan node. Gambar 5 menunjukkan peta yang telah dikonfigurasi menggunakan simulator SUMO. SUMO adalah sebuah aplikasi simulator yang digunakan untuk membuat simulasi pergerakan kendaraan pada satu jalur tertentu. Dengan mengkombinasikan SUMO dengan openstreetmap.org dapat disimulasikan lalu lintas dengan lokasi beragam di dunia. SUMO digunakan untuk mengkonfigurasi peta agar simulasi mendekati keadaan yang sebenarnya.

\subsection{Parameter Simulasi}

Pada penelitian ini simulasi dilakukan selama 300 detik dengan menggunakan skenario di lingkungan perkotaan (urban). Kemudian diujikan faktor perubahan jumlah node yang bisa mempengaruhi kinerja dari layanan VANET dari protokol routing yang dibandingkan. Ukuran paket data yang digunakan adalah 512 bytes dan CBR akan mengirimkan data setiap 0,25 detik dan rate diatur sebesar $512 \mathrm{kbps}$. Beberapa parameter yang diatur dalam script skenario dapat dilihat pada Tabel 1 dibawah ini.

Tabel 1. Parameter Simulasi

\begin{tabular}{ll}
\hline Parameter & Nilai DSR dan TORA \\
\hline Area Simulasi & $1000 \times 1000 \mathrm{~m}$ \\
Waktu Simulasi & 300 detik \\
Model Antena & Omnidirectional \\
MAC Type & IEEE $802.11 \mathrm{p}$ \\
Lingkungan Simulasi & Urban \\
Pergerakan Node & Random Way Point \\
Jumlah Node & $5,10,20,40,80$ \\
Kecepatan Node & $20 \mathrm{~km} / \mathrm{jam}$ \\
Protokol Transport & UDP \\
Traffic Model & CBR \\
Data Packet Size & 512 bytes \\
\hline
\end{tabular}

\subsection{Parameter Uji Performansi}

QoS merupakan suatu hasil efek dari performansi sebuah layanan secara kolektif yang menentukan tingkat kepuasan pelanggan terhadap layanan yang digunakan. Berikut penjelasan paramaeter QoS yang diuji pada penelitian ini.

\section{Throughput}

Throughput merupakan laju bit sebenarnya pada jaringan dan menunjukkan jumlah paket data yang berhasil diterima setiap detiknya. Rumus menghitung throughput yaitu :

$$
\text { Throughput }=\frac{\text { Jumlah paket data yang diterima }}{\text { waktu pengiriman paket data }}
$$




\section{Packet Loss}

Packet loss merupakan presentase jumlah paket yang gagal diterima oleh tujuan. Rumus menghitung packet loss yaitu :

$$
\text { Packet loss }=\frac{\text { paket data tx }- \text { paket data } r x}{\text { paket data } r x} \times 100 \%
$$
dimana

$t x=$ paket data yang dikirim

$r x=$ paket data yang diterima

\section{Packet Delivery Ratio (PDR)}

Packet delivery ratio merupakan rasio antara banyaknya paket yang diterima oleh tujuan dengan banyaknya paket yang dikirim oleh sumber. Rumus menghitung packet delivery ratio yaitu :

$$
P D R=\frac{\text { paket data } r x}{\text { paket data } t x} \times 100 \%
$$

\section{Delay}

Delay merupakan lamanya waktu tunda yang dibutuhkan oleh data atau informasi untuk sampai ke tujuan. Rumus menghitung delay yaitu :

$$
\text { Delay }=\text { waktu paket } r x-\text { waktu paket } t x
$$

\section{Collision Rate}

Collision rate merupakan total paket yang tertumpuk dalam satu periode. Rumus menghitung collision rate yaitu :

$$
\text { Collision rate }=\left(\frac{\text { jumlah collision }}{\text { paket data yang dikirim }}\right)
$$

\section{Hasil dan Analisis}

Pengujian dilakukan berdasarkan skenario pengujian yang telah dijelaskan sebelumnya yaitu menguji performansi dua routing protocol yaitu DSR dan TORA terhadap perubahan jumlah node pada jaringan VANET. Simulasi dilakukan menggunakan Network Simulator versi 2.35 selama 300 detik.

\subsection{Throughput}

Nilai throughput akan semakin baik apabila mendekati nilai sending rate, pada penelitian ini yaitu sebesar 512 kbps. Gambar 6 menunjukkan bahwa dengan menggunakan protokol DSR, throughput semakin meningkat seiring bertambahnya jumlah node. Hal ini dapat dikarenakan DSR membentuk rute sesuai permintaan dan tergantung pada sumber routing daripada routing table untuk semua node tujuan yang dapat dicapai pada jaringan. Berbeda dengan routing DSR, pada routing TORA terjadi penurunan throughput seiring bertambahnya jumlah node. Hal ini dapat disebabkan karena inisiasi routing yang kompleks yaitu dengan menyediakan banyak jalur (multipath) sehingga membutuhkan bandwidth cukup besar.

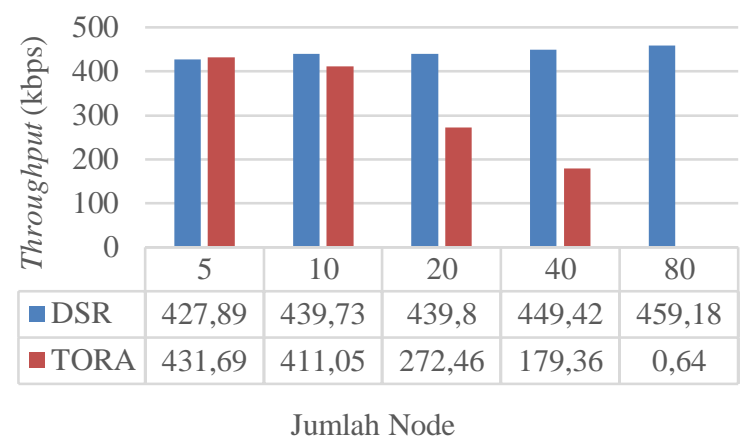

Gambar 6. Performansi Throughput Terhadap Perubahan Jumlah Node

\subsection{Packet Delivery Ratio}

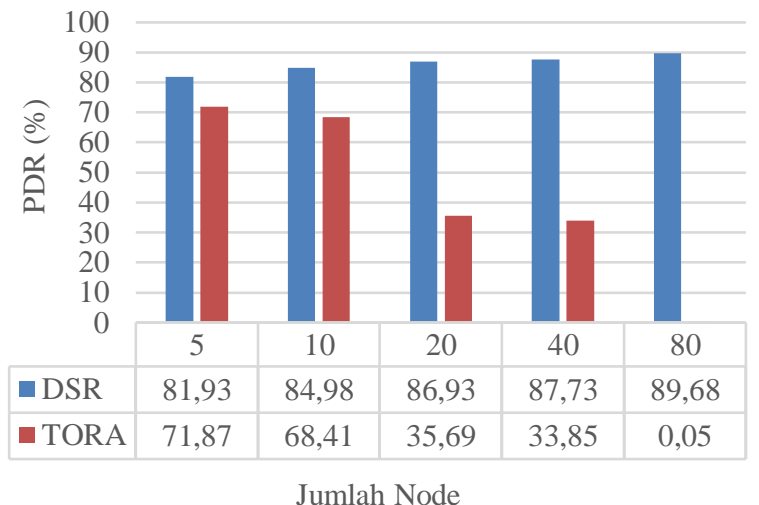

Gambar 7. Performansi PDR Terhadap Perubahan Jumlah Node

PDR merupakan presentase keberhasilan suatu data dikirim. Semakin besar nilai PDR (mendekati nilai 100\%) maka semakin baik kinerja suatu jaringan. Gambar 7 menunjukkan bahwa nilai PDR pada routing DSR semakin meningkat dibanding routing TORA seiring bertambahnya jumlah node. Pada DSR dengan adanya route cache membuat kerja routing DSR effisien. Route cache berisikan rute yang telah dibangun. Sehingga jika terdapat node yang ingin berkomunikasi kembali tidak perlu melakukan route discovery lagi. Sedangkan PDR pada TORA mengalami penurunan. Setiap node pada TORA hanya mengetahui informasi node tetangga (one hop) dan tidak memiliki route cache. Secara teori, TORA bekerja dengan membangun banyak jalur sehingga ketika terjadi link failure terdapat jalur alternatif yang masih bisa digunakan. Namun pada hasil penelitian menunjukkan bahwa semakin banyak node, semakin tinggi kemungkinan link failure terjadi dan menyebabkan performansi routing tersebut menurun. 


\subsection{Packet Loss}

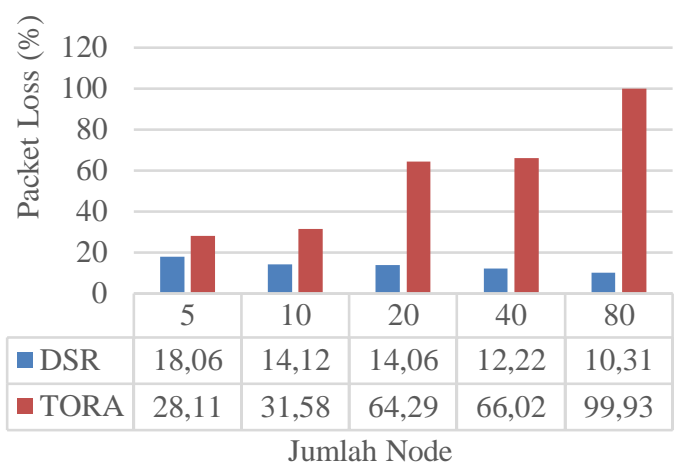

Gambar 8. Performansi Packet Loss Terhadap Perubahan Jumlah Node

Packet loss merupakan banyaknya data yang hilang selama proses pengiriman data, sehingga data yang diterima tidak sama dengan jumlah yang dikirim. Semakin kecil nilai packet loss, semakin baik kinerja jaringan. Gambar 8 menunjukkan bahwa seiring bertambahnya jumlah node, packet loss routing DSR semakin menurun dengan nilai rata-rata sebesar $13,75 \%$. Sedangkan pada routing TORA mengalami kenaikan sebesar 57,98\%. Packet loss dapat dipengaruhi oleh banyaknya hop yang dilewati pada kedua routing. Karena routing TORA bekerja secara multipath maka kemungkinan hop yang dilewati akan lebih banyak dibandingkan routing DSR. Proses update table routing ketika terjadi link failure, akan mengubah jalur yang dilewati oleh data. Meskipun menyediakan jalur alternatif, TORA tidak memprioritaskan shortest path karena menghindari terjadinya overhead. Sehingga tidak menutup kemungkinan akan menggunakan jalur yang panjang. Packet loss yang semakin besar dapat juga dipengaruhi oleh tabrakan data yang terjadi akibat penggunaan bandwidth yang berlebih pada suatu jaringan.

\subsection{Delay}

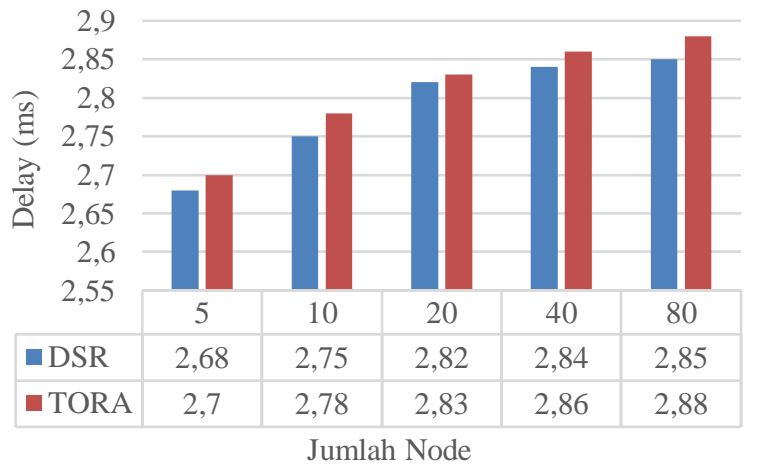

Gambar 9. Performansi Delay Terhadap Perubahan Jumlah Node
Delay merupakan waktu tunda yang terjadi selama proses pengiriman data. Gambar 9 menunjukkan nilai delay pada routing DSR lebih baik dengan nilai rata-rata sebesar 2,78 $\mathrm{ms}$ jika dibandingkan dengan routing TORA dengan nilai rata-rata $2,81 \mathrm{~ms}$. Nilai kecil pada delay menunjukkan kinerja jaringan yang baik. Secara teori semakin banyak node, maka nilai delay akan semakin besar dikarenakan waktu antrian paket dan waktu proses paket yang ditransmisikan. Keunggulan DSR dapat dipengaruhi adanya route cache yang menyimpan data route yang telah dibangun, sehingga tidak memerlukan route discovery kembali. Pada dasarnya inisiasi routing TORA lebih kompleks dibanding DSR sehingga membutuhkan waktu yang lebih lama. Semakin banyak node pada routing TORA, maka akan banyak jalur alternatif yang dibangun. Secara teori, TORA bekerja dengan height metric pada tiap node. Data akan dikirim saat node sumber mempunyai height yang lebih tinggi dibanding intermediate node dan node tujuan sehingga dapat dikatakan bahwa routing TORA kesulitan mencari jalur serta membutuhkan waktu yang lebih lama.

\subsection{Collision Rate}

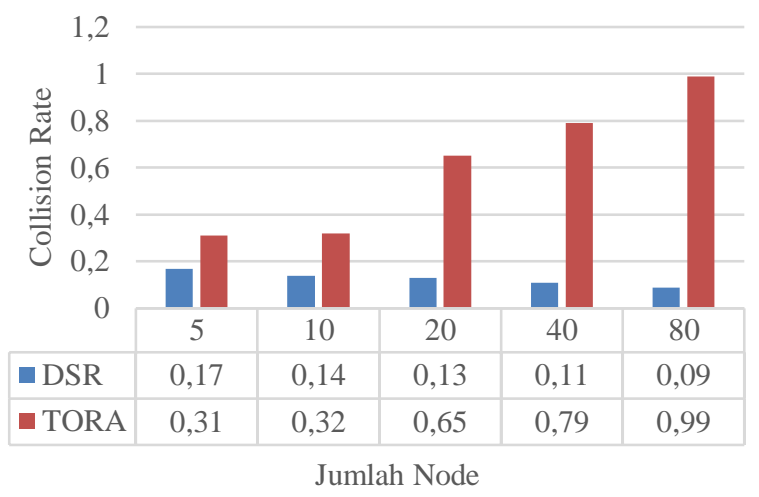

\section{Gambar 10. Performansi Collision Rate Terhadap Perubahan Jumlah Node}

Collision rate menunjukkan tabrakan data yang terjadi pada jaringan. Pada Gambar 10 dapat dilihat bahwa collision rate pada DSR mengalami penurunan, hal ini dikarenakan routing DSR bersifat beacon less yang artinya membangun rute sesuai permintaan node sumber. Sehingga menghindari terjadinya bandwidth overhead yang dapat menyebabkan tabrakan data akibat terjadinya penumpukan data dijaringan. Sedangkan pada TORA terjadi kenaikan collision rate hal ini dapat terjadi karena routing TORA banyak membangun jalur alternatif dan membutuhkan bandwidth yang cukup besar sehingga dapat mengakibatkan kanal tidak mampu menampung data dan saling bertabrakan. 


\section{Kesimpulan}

Berdasarkan hasil penelitian dapat disimpulkan bahwa secara umum performansi routing DSR lebih baik dibandingkan routing TORA untuk parameter throughput, packet delivery ratio, packet loss, delay dan collision rate. Ditinjau dari hasil pengujian parameter, probabilitas terjadinya tabrakan data lebih tinggi jika menggunakan routing TORA dibanding menggunakan routing DSR. DSR mengalami kenaikan performansi untuk skenario perubahan jumlah node dengan nilai rata-rata throughput sebesar 443,204 kbps, packet delivery ratio sebesar $86,25 \%$, packet loss sebesar $13,75 \%$, delay sebesar 2,78 $\mathrm{ms}$ dan collision rate sebesar 0,12 . Sedangkan untuk routing TORA mengalami penurunan performansi dengan nilai rata-rata throughput sebesar 259,04 kbps, packet delivery ratio sebesar 41,97\%, packet loss sebesar $57,98 \%$, delay sebesar $2,81 \mathrm{~ms}$ dan collision rate sebesar 0,61 . Oleh karena itu, dapat dikatakan bahwa routing TORA kurang cocok untuk lingkungan dengan jumlah node yang padat karena memungkinkan peningkatan penggunaan bandwith yang dapat menyebabkan performansi routing tersebut menurun. Untuk keperluan pengembangan penelitian disarankan agar memperhitungkan obstacle serta keamanan jaringan pada VANET.

\section{Referensi}

[1] P. Mutalik, S. Nagaraj, J. Vedavyas, R. V. Biradar, and V. G. C. Patil, "A comparative study on AODV, DSR and DSDV routing protocols for Intelligent Transportation System (ITS) in metro cities for road traffic safety using VANET route traffic analysis (VRTA)," 2016 IEEE Int. Conf. Adv. Electron. Commun. Comput. Technol. ICAECCT 2016, pp. 383386, 2017.

[2] R. Michoud and A. Mar, "Mobile Ad-Hoc Routing Protocols Survey for the Design of VANET Applications," 2012.

[3] W. Liang, Z. Li, H. Zhang, S. Wang, and R. Bie, "Vehicular Ad Hoc Networks : Architectures, Research Issues , Methodologies , Challenges , and Trends," vol. 2015, 2015

[4] K. Deepa Thilak and A. Amuthan, "DoS attack on VANET routing and possible defending solutions-A survey," 2016 Int. Conf. Inf. Commun. Embed. Syst. ICICES 2016, no. Icices, 2016.

[5] N. S. Patel and S. Singh, "A Survey on Techniques for Collision Prevention in," pp. 4-7, 2016.

[6] K. Priya, "On the Selection of Efficient Routing Protocol for 802 . 11p Interface in VANET," pp. 617622, 2016.

[7] T. E. Ali and L. A. Khalil, "Review and Performance Comparison of VANET Protocols: AODV, DSR, OLSR, DYMO, DSDV \& ZRP," 2016.

[8] K. Majumder and S. K. Sarkar, "Performance analysis of AODV and DSR routing protocols in hybrid network scenario," Proc. INDICON 2009 - An IEEE India Counc. Conf., vol. 2, no. 2, 2009.

[9] P. Sankar, V. Lakshmi, and K. Aishwarya, "Study on the Performance of Ad-hoc Routing Protocols on vehicles," pp. 656-661, 2011.

[10] M. Yadav, "Multi-Hop Wireless Ad-Hoc Network Routing Protocols- A Comparative Study of DSDV , TORA, DSR And AODV,” 2015. 